\title{
Energy transitions and trade law: Lessons from the reform of fisheries subsidies
}

Margaret A. Young

Associate Professor

Melbourne Law School

University of Melbourne, Australia

Email: m.young@unimelb.edu.au

Phone: +61 383441097

\begin{abstract}
Fossil fuel subsidies, like subsidies to the fishing sector, lead to trade-distorting and ecologically harmful practices. The US $\$ 35$ billion in subsidies provided by countries every year to the fishing sector leads to more and more boats being built, even as $90 \%$ of fish stocks are either fully exploited or overfished. An estimated US $\$ 444$ billion in subsidies are provided annually for the production of fossil fuels by G20 countries, even as evidence emerges that oil, gas and coal reserves must remain unexploited to limit global warming increases to $2^{\circ}$ Celsius. Of course, each country has its own development priorities, livelihood concerns and need for food and energy security. Agreeing upon subsidy reform is a complex undertaking that requires the assessment of social, political and historical considerations, as well as the involvement of international and transnational legal regimes that govern climate change, energy, fisheries and trade. This article reviews proposals for reform within the World Trade Organization and regional trade agreements, including the new disciplines on fisheries subsidies that were endorsed in the text of the Trans-Pacific Partnership. Although the
\end{abstract}


latter agreement is unlikely to enter into force, consensus is emerging on the need to prohibit subsidies that contribute to overfishing or that are linked to illegal, unreported or unregulated fishing. The article shows how these legal developments might inform attempts to limit fossil fuel production and consumption subsidies. It highlights the need for learning and open deliberation about subsidy reform by affected stakeholders, including representatives from international organizations and civil society. It also points to new arrangements that link compliance with subsidy rules to standards and benchmarks from fisheries regimes, and demonstrates how such inter-regime connections are legitimate in the context of the fragmentation of international law. While reform to fisheries subsidies is still preliminary and fraught, there are useful lessons for the equally important project of energy transitions.

\section{Keywords}

climate change; fisheries subsidies; fossil fuel subsidies; Trans-Pacific Partnership, WTO

\section{Abbreviations}

$\mathrm{ACP}$

ASCM

FAO

FFFSR

G20

GATT

ICTSD

IEA
Africa, Caribbean and Pacific Group of States

Agreement on Subsidies and Countervailing Measures

Food and Agriculture Organization of the United Nations

Friends of Fossil Fuel Subsidy Reform

Group of 20

General Agreement on Tariffs and Trade

International Centre for Trade and Sustainable Development

International Energy Agency 
International Monetary Fund

IPCC

Intergovernmental Panel on Climate Change

IUU

Illegal, unreported, and unregulated

MSY

Maximum sustainable yield

RFMO

Regional fisheries management organization

RTA

Regional trade agreement

SDG

Sustainable Development Goal

TPP

Trans-Pacific Partnership

UN

United Nations

UNCTAD

United Nations Conference on Trade and Development

UNEP

United Nations Environment Programme

US

United States

WTO

World Trade Organization

WWF

World Wide Fund for Nature

\section{Introduction}

Policy makers are increasingly seeking to address the economic structures that incentivize over-exploitation of finite resources. In fisheries, scientists have offered estimates of the current state of fish stocks, demonstrating that over $30 \%$ are overfished and 58\% are fully fished (FAO 2016). In atmospheric studies, scientists have devised a 'carbon budget', which shows how much carbon can be burned before an increase in global warming exceeds $2^{\circ}$ Celsius (IPCC 2013). At the same time, studies on economic arrangements show that subsidies (defined as financial support provided by government to an industry) lead to trade distortions and ecological 
devastation. Fisheries subsidies as high as US\$35 billion annually (Sumaila et al. 2013) promote the enhancement of vessel capacity and fishing operations to catch fewer and fewer available fish. Fossil fuel subsidies for the production of fossil fuels - estimated at US $\$ 444$ billion a year for the Group of 20 (G20) countries alone (Bast et al. 2015) — promote the exploration and exploitation of oil, gas and coal reserves that are outside of our 'carbon budget'. Consumption subsidies for fossil fuels, which lower the price for energy consumers, were estimated to be US\$325 billion in 2015 (IEA 2016).

This article considers parallels and differences in the governance of energy subsidies and fisheries subsidies, with a focus on the trade regime as a driver for reform. In Section 2, it analogizes the trade-distorting and ecologically destructive characteristics of fisheries and fossil fuel subsidies, and points to the fact that classification of such subsidies is a difficult and politically sensitive exercise in both the marine and energy sectors. Differentiation between production and consumption subsidies is an important part of this discussion. Section 3 then moves to review efforts at fisheries subsidies reform at the World Trade Organization (WTO) and regional trade agreements. For example, before the newly elected US administration withdrew from the Trans-Pacific Partnership (TPP) in early 2017, the signed text contained important subsidy disciplines in the marine sector. The article considers the proposed text and other reform efforts and argues that subsidy rules depend upon inter-regime learning and the open deliberation by affected actors, both in the negotiation of new provisions and in the ongoing entrenched links that ground prohibitions in existing institutions such as the Food and Agriculture Organization (FAO). This requires outreach between trade and other international regimes that is not dependent on uniform membership by all states in the regimes. Such a conception 
of regime interaction allows the sovereign underpinnings of international law to be updated by new conceptions of legitimacy that emerge from transparency, open participation and ongoing deliberation. The article compares similar initiatives in the context of fossil fuel subsidy reform and concludes by outlining the major implications for energy subsidies reform in the context of the fragmentation of international law.

\section{Parallels in problem definition}

The definition of subsidies that have trade implications is informed by WTO agreements. Specifically, the Agreement on Subsidies and Countervailing Measures (ASCM), which still regulates two categories of subsidies and governs the trade policies of all 164 WTO members, provides for: (i) prohibited subsidies, which boost export performance or require and favour local content; and (ii) actionable subsidies, which can give members grounds for challenging subsidies based on their ability to cause economic injury, serious prejudice and an impairment of the benefits to states as outlined in the General Agreement on Tariffs and Trade (GATT) of 1994. The legal categories of subsidies are explained in more detail in Section 3, but for the purposes of the current section it is important to note that the definition of 'good' and 'bad' energy subsidies, like 'good' and 'bad' fisheries subsidies, requires an awareness of assumptions, contexts and values. The problems that are created when a state provides financial support for an industry or business in the energy or marine sector are both environmental and economic. But addressing those problems involves assumptions about the appropriate role of the state; such assumptions have more importance than mere trade relations. This section situates this issue by providing some comparisons 
of the fisheries and fossil fuel contexts and calling for caution and sensitivity when the trade regime seeks to discipline subsidies.

The methodologies used for the calculation of subsidies are varied, but the numbers are generally very high. The IEA's estimate of US\$325 billion for fossil fuel consumption subsidies in 2015 (IEA 2016) can be compared to estimates of as much as US $\$ 650$ billion for global fossil fuel subsidies from a 2013 forecast using International Monetary Fund (IMF) methodologies (Whitley and van der Burg 2015). In the fishing context, one estimate is that global fisheries subsidies amounted to around US\$35 billion in 2009 (Sumaila et al. 2013). Much of these subsidies lead to trade distortions: in the energy context, a path dependency on carbon-intensive practices and a higher price of renewable alternatives (Coady et al. 2015); in the fisheries context, an expansion of redundant global fishing fleet capacity and the extension of fishing that would be otherwise economically unsustainable. Data indicates that marine fisheries operate globally at a net economic loss, with overfishing estimated at leading to economic losses of about US\$83 billion in 2012 (World Bank 2016).

These figures are based on estimates of a finite resource. ${ }^{1}$ Whereas climate scientists and policy makers have developed the notion of a 'carbon budget' to demonstrate how much carbon can be burned to keep to a certain amount of global warming, a similar evaluation has been made of fisheries stocks, although the concept of 'maximum sustainable yield' (MSY) is more specific as to stocks. MSY provides for the maximum catch that can be extracted from a fish population in the long term,

\footnotetext{
${ }^{1}$ While economic classifications such as Journal of Economic Literature (JEL) codes may contrast these natural resources as non-renewable (hydrocarbon resources) and renewable (fisheries), the WTO has recognized living resources including fish to be an exhaustible natural resource (WTO 1998).
} 
and leads to computations of 'total allowable catch' that are set for particular fisheries. The fraction of stock fished at biologically sustainable levels is currently decreasing, and in $2013,31 \%$ of fish stocks were fished at a biologically unsustainable level and are therefore overfished, while over $58 \%$ were fully fished (FAO 2016). Thus, a staggering $90 \%$ of fish stocks are at the verge of overexploitation (World Bank 2016). A significant proportion of traded fishincluding between 20 and $32 \%$ of all imports to the United States (US) - are estimated to be caught illegally, in a phenomenon known as 'illegal, unreported and unregulated' or 'IUU' fishing (Pramoda et al. 2014; Young 2016). This focus on production issues gives rise to an important comparison with fossil fuel subsidies: we will see that fisheries subsidies reform has readily confronted production subsidies, whereas similar efforts in the energy context have focused instead on subsidies for consumption of fossil fuels (see, e.g., FFFSR 2015).

An obvious contrast might be that overfishing occurs in particular stocks in specific geographical areas, while greenhouse gas emissions from the burning of fossil fuels are mixed in the atmosphere and are not contained in a particular place. Yet the UNFCCC already adopts a territorial notion of greenhouse gas emissions, in the sense that responsibilities for reducing emissions within their borders are allocated to states (Scott 2015). Indeed, it might be the fisheries context that presents a more complicated account of territory, given that overfishing occurs both within domestic fisheries (namely, within 'exclusive economic zones' or EEZs)_and the high seas. The FAO and regional fisheries management organizations (RFMOs) seek to allocate responsibility to states based on coastal proximity, location of ports or a state practice of registering fishing vessels to fly its flag (FAO 1993; FAO 1995). One might muse that this more demanding set of territorial questions has led to a more mature and 
developed fisheries management regime as compared to the diffuse set of governance arrangements in the global energy context.

Further analogies may be made with respect to the consequences of climate change and overfishing, which are well known to include environmental, social and economic issues. Global warming increases of more than $2^{\circ}$ Celsius will lead to grave impacts on human well-being, food production and natural systems, often through changes caused by extreme weather events (IPCC 2013). Fish stock depletion similarly threatens the productive capacity of the ocean, with food security a major concern: fish accounts for almost $17 \%$ of the global population's intake of animal protein, and that figure increases to over $50 \%$ for some coastal and island countries (FAO 2016). Indeed, it might be the low-lying coastal developing countries who are most vulnerable to both the consequences of climate change and the depletion of wild capture fisheries.

Fossil fuel subsidies and fisheries subsidies are not simply self-contained. In fact, out of the classifications of fisheries subsidies, as much as $22 \%$ of total fisheries subsidies are provided for fuel used by fishing vessels (Sumaila et al. 2013; 2016). This form of support lowers the costs of operating motorized vessels, and extends the capacity and reach of vessel operations, with direct and indirect impacts on overfishing (Von Moltke 2011; Martini 2012). Curtailing fossil fuel consumption subsidies would thus help to curtail fisheries subsidies and improve fish stock health. (The reverse scenario also applies, albeit obliquely: curtailing fisheries subsidies may be another form of climate change mitigation when one takes into account the newly 
established link between overfishing and climate change. ${ }^{2}$ More directly, the significant proportion of fisheries subsidies being used for fuel has an impact on greenhouse gas emissions). These links have begun to be recognized in efforts for reform, such as the proposed new annex to the ASCM, which proposes to prohibit certain fisheries subsidies (WTO 2007; see Section 3).

The overlap between fossil fuel consumption subsidies and fisheries subsidies alerts us to a broader issue in definitions and classifications. Ecologically destructive subsidies may be relatively easy to identify, as might the beneficial subsidies aimed at remedial measures in the fish or renewable energy sectors. Indeed, in the fisheries context a classification methodology has been developed that draws distinctions between (i) beneficial subsidies, (ii) capacity-enhancing subsidies, and (iii) ambiguous subsidies (Sumaila et al. 2010). 'Bad' fisheries subsidies can be identified as vessel capacity enhancing subsidies or other subsidies encouraging overfishing, including where the vessels are engaged in illegal, unreported or unregulated fishing (see also the formulation in WTO 2007). To extrapolate to the energy sector, 'bad' energy subsidies can be identified as those that lead to wasteful consumption (e.g. FFFSR 2015), or those that lead to the production of new carbon reserves that will exceed the carbon budget — especially fossil fuel production subsidies for exploration and coal (Bast et al. 2015). 'Good' fisheries subsidies are used to retrain fishers, or build and maintain improved management systems that help to withdraw fishing capacity, while 'good' energy subsidies might include support for research and development in renewable technologies. ${ }^{3}$ There is increasingly consensus on these

\footnotetext{
${ }^{2}$ For scientific evidence that fish excretions contribute an important role in maintaining the ocean's $\mathrm{pH}$ balance, see Wilson et al. 2009.

${ }^{3}$ Note that research and development may still amount to 'bad' subsidies under the ASCM, such as in the recent dispute concerning Boeing and Airbus (e.g., WTO 2012).
} 
policy approaches, despite the inherently political and even cultural assumptions. The areas in between are, however, much more complicated.

The middle ground of subsidies that might serve multiple objectives and lead to multiple consequences is a difficult and contested terrain. For example, should subsidies for disaster assistance be used to rebuild vessel capacity in decimated areas? Do artisanal fishers have greater claims to state support, even if their practices have ecologically adverse effects? Should the economic strength of countries be a factor in deciding on subsidy disciplines and special and differential treatment—or should distributional justice within countries be the defining feature? The same subsidy may even fall into different categories depending on circumstances: a subsidy used to decommission an existing vessel, which may be 'good' to reduce overcapacity of one state, may be 'bad' if the vessel is made available to another overexploited fishery (Porter 2004; see also WTO 2007, draft Article II(d)). There are also complexities within the fact that some countries can benefit economically from the subsidizing practices of other states: in the fisheries context, for example, subsidies may be used to procure access rights for fleets to fish in the distant waters of coastal states (Witbooi 2008), meaning that those (often developing) coastal states have reasons not to complain if the foreign subsidies have supported the payment of access fees.

It is useful to recall the major subsidizing states in this context: in fisheries, Japan provides the highest level of subsidies (19.7\%), followed closely by China (19.6\%); the US, Spain, and Korea complete the top five (Sumaila 2016). In the energy context, there is an estimated US $\$ 444$ billion spent annually by G20 countries to subsidize the production of fossil fuels, calculated to include including national subsidies, state-owned-enterprise investment and public finance (Bast et al. 2015). The leading subsidizers in the category of national subsidies for fossil fuel production 
in 2013 and 2014 have been estimated as Russia (US\$23 billion), the US (US\$20 billion), Australia and Brazil (US\$5 billion each) and China (US\$3 billion) (Bast et al. 2015). Meanwhile, of the global fossil fuel consumption subsidies estimated in 2015 to be US $\$ 325$ billion, the largest sources were Iran (US\$52 billion), Saudi Arabia (US\$49 billion), Russia (US\$30 billion) and Venezuela (US\$20 billion) (IEA 2016).

Even apart from these top subsidizers,, all countries have food security (and energy security) concerns which are pursued through various economic, political, security, and even cultural policies. Whether and how to develop an active (and competitive) fisheries and energy sector is an issue that clearly occupies the lobbyists and strategists within those industries (as public choice analyses have made clear) but also has ramifications for the social, political, and cultural identity of the state.

In that sense, defining the 'problem' of fisheries and fossil fuel subsidies runs into the familiar problem of how to draw boundaries around acceptable and nonacceptable government action. What is 'legal' is different from what is judged to be unsustainable. For trade lawyers, this has revolved around the definition of 'specificity' in the ASCM: that distortions would occur within an economy only by government conferral of benefits limited to specific industries (Horlick 2002). Moreover, a construction of the market can differentiate between supply-side features (WTO 2013a). This does not always answer the definitional issue, however: for example, fossil fuel subsidies are usually in a general form, as compared to the more specific renewable energy subsidies, and thus likely to escape disciplines (Meyer, this issue). Commentators have also pointed to the value-laden nature of the subsidy inquiry, where attending to distorting or 'artificial' prices might suggest there is a natural and incontestable role for states, which gives primacy to pricing as the best method for economic coordination and governance (Orford 2015). There is a deep 
concern that focusing on eradicating subsidies may lead to a denuded public realm, although there is disagreement as to whether these pressures come from the danger of exceptionalism or protectionism (Trebilcock 2015; Trebilcock and Pue 2015).

An awareness of the assumptions, values, philosophies, historic practices, and affected interests in the classification of subsidies is necessary in the fisheries and energy contexts. As such, the goal of moving towards a low-carbon (or sustainably fished) economy should not be elided with a goal of reducing all interventions in the free operation of markets. Specific and evidence-based contexts must be targeted, based on negotiated reciprocal arrangements including, where relevant, differential treatment. An account of complexity, diversity, and pluralism is necessary for these efforts, which makes the question of 'who decides' a central one, as I discuss in the following section.

\section{Governance of fisheries subsidies: multilateral and regional regimes}

The need to address fisheries subsidies and energy subsidies has been recognized in many international forums. For energy subsidies, this recognition has been made repeatedly by the G20, in annual communiqués committing G20 governments to phase out fossil fuel subsidies since 2009. The UNFCCC Conference of the Parties at Paris in 2015 also featured the launch of a 'Fossil Fuel Subsidy Reform Communiqué,, endorsed by at least 40 states (FFFSR 2015), as well as some unilateral domestic intentions to reform fossil fuel subsidies as part of the nationally determined contributions of states (van Asselt and Kulovesi, this issue). For fisheries, multilateral recognition of the need for reform came earlier. The 2002 World Summit on Sustainable Development urged states to eliminate subsidies contributing to IUU 
fishing and overcapacity (UN 2002, para. 31), and a deadline of 2020 has been set for these efforts by the recently agreed Sustainable Development Goals (SDGs) (UN 2015, Goal 14.6). The FAO has urged states to take measures 'to ensure that fishing effort is commensurate with the productive capacity of the fishery resources and their sustainable utilization' (FAO 1995, Article 6.3; Article 7.4.3) and has issued plans of actions for states to unilaterally reduce subsidies that contribute to the build-up of excessive fishing capacity (FAO 1999a; 1999b). The FAO has also partnered with other United Nations agencies to mark support for fisheries subsidies reform and the SDGs, an initiative that has been formally acknowledged by 90 states (UNCTAD et al. 2016). Yet it is the trade regime that has the most effective enforcement mechanisms for subsidy disciplines, and it has become the focal point for reform efforts. This section examines the role of the WTO and regional trade agreements in the legal reform of fisheries subsidies.

\subsection{World Trade Organization}

The WTO has become a focal point due to its established system of disciplining certain subsidies, as encapsulated in the ASCM. While on its face the ASCM does discipline subsidies, its application has been poorly targeted in both the fisheries and energy contexts.

The ASCM prohibits 'red-box' subsidies that are contingent on exports, or on the use of domestic rather than imported goods (Article 3; see also Articles 2 and 1.2). Because the majority of fisheries subsidies are granted by countries such as Japan that are net importers of fish, and are usually designed to encourage domestic fish supply 
rather than exports, the category of prohibited subsidies is often inapplicable to the fisheries context.

The ASCM also contains an 'amber-box' on actionable subsidies that are assessed according to their adverse effects on the trade interests of other WTO members, which must be specific to a particular enterprise or industry (Articles 1.2 and 2) and which are assessed according to injury to the domestic industry of another member, the nullification or impairment of benefits of another member or serious prejudice to the interests of another member (Article 5). Once again, the fisheries context presents difficulties, especially because it is the access to the resource that is likely to be distorted by fisheries subsidies, although price is also undoubtedly affected. As documented by De Bièvre et al. (this issue) and Meyer (this issue), the amber box can be also difficult to meet for fossil fuel subsidies-even though renewable energy subsidies have been litigated repeatedly at the WTO. Finally, a 'green-box' that allowed for particular subsidies for the adaptation of existing facilities to environmental sustainability, has lapsed under the existing ASCM framework (Articles 8 and 9). ${ }^{4}$

Given the perceived inadequacies of the ASCM to curtail subsidizing practices of WTO members, efforts have been launched to amend it. In 2001, WTO members agreed to negotiate to 'aim to clarify and improve WTO disciplines on fisheries subsidies, taking into account the importance of this sector to developing countries', as part of a wider scale reform of the ASCM and the Anti-Dumping Agreement within the Doha Development Round of WTO negotiations (WTO 2001, para. 28). WTO members acknowledged the environmental dimension to the fisheries subsidies

\footnotetext{
${ }^{4}$ The provision was adopted on a provisional basis for a period of five years (Article 31). When it expired on 31 December 1999, a lack of consensus among WTO members meant that it was not renewed.
} 
negotiations by referring to the mutual supportiveness of trade and environment (WTO 2001, para. 31), and in 2005 Ministers restated this intention as follows (WTO 2005, Annex D, para. 9):

[We] recall our commitment at Doha to enhancing the mutual supportiveness of trade and environment, note that there is broad agreement that the Group should strengthen disciplines on subsidies in the fisheries sector, including through the prohibition of certain forms of fisheries subsidies that contribute to overcapacity and over-fishing, and call on Participants promptly to undertake further detailed work to, inter alia, establish the nature and extent of those disciplines, including transparency and enforceability. Appropriate and effective special and differential treatment for developing and least-developed Members should be an integral part of the fisheries subsidies negotiations, taking into account the importance of this sector to development priorities, poverty reduction, and livelihood and food security concerns.

In 2007, the then Chair of the Rules Group circulated a draft consolidated text of the proposed disciplines in the form of a proposed new annex to the ASCM (WTO 2007), which led to both supportive and critical views by negotiating members (WTO 2008). As detailed in Young 2009, one strong position was taken by an informal grouping of WTO members self-named 'Friends of Fish', 5 which was based on a conviction of the link between enhanced subsidy disciplines and trade, environmental, and development needs. Another position was taken by a group that included Japan,

\footnotetext{
5 Membership varies according to time and the content of submissions. Members have included Australia, Chile, Ecuador, Iceland, New Zealand, Peru, Philippines, and the US.
} 
Korea, Taiwan, and others; this group contested the inevitability of the link between subsidies and environmental damage, and instead asserted that inadequate fisheries management is the main cause of unsustainable fishing. The reliance on management attracted strong criticism from other WTO members. Indeed, it is not clear that fisheries management can ever be an effective restraint on incentives for increased production in practice (Tipping 2016).

In 2011, a subsequent Chair released a report summarizing the state of the 2007 Chair's text and pointed to areas of support (WTO 2011). In 2013, at the WTO Ministerial Conference in Bali, the Friends of Fish reiterated its commitment to 'ambitious and effective disciplines on fisheries subsidies' and pledged to 'work within the WTO and other fora to improve fisheries subsidies reform and transparency' (WTO 2013b). This was followed in 2015 by submissions proposing multilateral prohibitions on subsidies for certain activities, such as subsidies on activities affecting overfished stocks and subsidies provided to any vessel engaged in illegal, unreported or unregulated fishing (WTO 2015a; 2015b).

Although the momentum for reform has been largely maintained in the WTO negotiations, it is hampered by the overarching delay in the entire Doha Development Round. The round operates as a 'single undertaking', according to which agreement is contingent on the conclusion of all negotiations, which span a variety of highly contentious topics including agriculture subsidy reform. Although the single undertaking has proved successful in other WTO rounds (and in other contexts, such as the United Nations Convention on the Law of the Sea), given that it forces negotiators to make trade-offs and compromises among linked issues, the current WTO negotiations are woefully slow. At the 2015 WTO Ministerial Conference in Nairobi, some WTO members departed from a reaffirmation of the Doha mandate, 
preferring to support 'new approaches' to the multilateral negotiations (WTO 2015c, para. 30). In September 2016, a group of WTO members reiterated their desire to achieve reform at the WTO to prohibit harmful fisheries subsidies, but intimated that they wished to work with each other and like-minded participants to conclude an agreement, presumably in plurilateral form (WTO 2016a).

In December 2016, three separate proposals were presented to the WTO negotiating group. The EU, the Africa, Caribbean and Pacific (ACP) group and a grouping of Latin American members comprising Argentina, Colombia, Costa Rica, Panama, Peru and Uruguay submitted proposals which included textual revisions to the ASCM (WTO 2016b; 2016c; 2016d). What these proposals have in common is their call for a multilateral outcome to be achieved in time for the $11^{\text {th }}$ WTO Ministerial Conference to be held in Buenos Aires in 2017. They also include as their objectives the achievement of SDG 14.6, which has 2020 as its deadline, and a recognition of the need for special and differential treatment for developing and least developed countries. While this renewed enthusiasm is promising, it must attract the attention of trade delegates whose time and resources continue to be diverted from the Doha Round and consumed by negotiations for bilateral or regional trade and investment agreements. Yet, as is discussed below, the multilateral proposals have clearly influenced the proposed disciplines in regional trade agreements (and vice versa). While a multilateral solution to fisheries subsidies may be still some time away, the trade regime is far from quiet on the need for reform.

\subsection{Regional trade agreements}


In addition to WTO obligations, many states are now subject to separate trade obligations contained in preferential or regional trade agreements (RTAs). These agreements are intended to create closer integration between the economies of the countries that are party to such agreements (see also Article XXIV.4 GATT) and increasingly include commitments on standards of treatment for investors. They have proliferated in recent years, so that a large percentage of global trade is subject to their terms. ${ }^{6}$ A notable example is the Trans-Pacific Partnership, which was awaiting ratification by 12 participating countries including Japan, the US, Canada, Chile, Mexico, Peru, and Vietnam, before the US withdrew its support in early 2017. Negotiations on the TPP concluded in 2015, and its text was signed but not ratified by the participating states. Had it come into force, the TPP would have applied to a significant proportion of the global fish trade: Japan and the US are the top two importers of fish products, while the US, Vietnam, Chile, and Canada are some of the biggest exporters (FAO 2016). Even though the TPP is unlikely to enter into force, the moment in time in which participating states concluded their negotiations and signalled a preparedness to develop new rules on subsidies is significant, and the signed text is likely to continue to influence reform efforts. For that reason, a detailed account of its fisheries subsidies provisions is provided here.

The TPP text contained legal provisions that largely reproduced the GATT and WTO approach to non-discrimination and exceptions (Chapter 29), but it went further in setting out a separate 'environment chapter' (Chapter 20). This chapter included an extensive section on marine capture fisheries. Parties were to seek to

\footnotetext{
6 See http://www.wto.org/english/tratop_e/region_e/rta_pta_e.htm; see also http://www.rtaexchange.org.
} 
operate a fisheries management system that would be designed inter alia to prevent overfishing and overcapacity (Article 20.16.3). Article 20.16.5 provides:

The Parties recognise that the implementation of a fisheries management system that is designed to prevent overfishing and overcapacity and to promote the recovery of overfished stocks must include the control, reduction and eventual elimination of all subsidies that contribute to overfishing and overcapacity. To that end, no Party shall grant or maintain any of the following subsidies within the meaning of Article 1.1 of the [ASCM] that are specific within the meaning of Article 2 of the [ASCM]:

(a) subsidies for fishing that negatively affect fish stocks that are in an overfished condition; and

(b) subsidies provided to any fishing vessel while listed by the flag State or a relevant Regional Fisheries Management Organisation or Arrangement for IUU fishing in accordance with the rules and procedures of that organisation or arrangement and in conformity with international law. [footnotes omitted]

The provision also required TPP parties to improve their compliance with notification obligations according to the ASCM and to include information relevant to the fishery for which a subsidy is provided, including catch data, fleet capacity, status of the fish stocks (e.g., overexploited, depleted, fully exploited, recovering or underexploited) and total imports and exports per species (Article 20.16.10). Information about fuel subsidies is also required to be provided (Article 20.16.11). Apart from the subsidies listed in Article 20.15.5(a) and (b), parties are to make best efforts to refrain from introducing and extending subsidies within the meaning of 
Article 1.1 of the ASCM (Article 20.16.7), although this must 'tak[e] into consideration a Party's social and developmental priorities, including food security concerns', presumably leading to differential treatment for developing countries that were TPP parties.

The TPP environment chapter included a range of mechanisms for enforcement, some of which followed the US model of free trade agreements. For example, it established an Environment Committee to oversee the implementation of the chapter (Article 20.19). It also allowed for environment consultations (Articles 20.20-20.22), which, if ineffective, might have led to the establishment of a dispute settlement panel (Article 20.23). By these terms, the fisheries subsidies provisions could be subject to compulsory dispute settlement. At the time when TPP parties concluded negotiations and signed the text, this signalled a willingness by them to engage in forms of dispute resolution that for some were novel. Reviewing the practices of similar structures such as the North American Free Trade Agreement (e.g., Markell 2004) would help to evaluate the impact such mechanisms might have had.

Although the TPP will probably never enter into force in its current form, it is undeniably significant that a small group of high-producing, high-consuming fisheries nations recognized the need to prohibit certain fisheries subsidies at the time of signing. This includes significant subsidizing states such as Japan and the US, who have failed to reach agreement at the WTO. It also includes parties that have failed to adopt national plans of actions to address IUU fishing or implemented the FAO 
Compliance Agreement (FAO 1993) in the past. ${ }^{7}$ This gives rise to the question of interaction with other regimes (Section 4).

It is also significant that the latest round of proposals at the WTO have incorporated some or all of the elements of reform set out in the TPP environment chapter. For example, the proposal by the ACP group of members would prohibit subsidies 'to fishing vessels or fishing activity negatively affecting fish stocks that are in an overfished condition', as well as subsidies provided to vessels or operators engaged in IUU fishing (WTO 2016c). The EU also links prohibitions to subsidies implicated in IUU fishing, evidenced from the IUU fishing vessel list of that party or an RFMO. Moreover, the EU proposal prohibits subsidies that 'support the acquisition of equipment that increases the ability of a fishing vessel to find fish' as well as subsidies that increase construction, capacity or importation of vessels (WTO 2016b). The proposal from some Latin American countries refers to the need to define the terms 'IUU fishing', 'overfishing', 'overcapacity', and 'artisanal fisheries' (WTO 2016d).

In summary, the governance of fisheries subsidies has followed a trajectory that has incorporated both multilateral and regional/bilateral trade forums. Attempts to address fossil fuel subsidies are following a similar trajectory. The issue has been raised obliquely a few times by negotiating states in the Doha Round: both the US and the EU have submitted proposals that could have relevance. The US proposed to expand the category of prohibited subsidies to include 'those instances of government intervention that have a similarly distortive impact on competitiveness and trade as do export and import substitution subsidies' (WTO 2006a). The EU wished instead to

\footnotetext{
${ }^{7}$ Brunei, Malaysia, Mexico, Peru, Singapore, and Vietnam.
} 
focus on an individual member's ability to address the adverse impacts of subsidies (WTO 2006b), thought to relate especially to the disciplining of dual pricing for fossil fuels (Lang et al. 2010). These proposals can be situated in the context of pre-Doha Round discussions too (Bigdeli 2008). Specific experiences with energy reform from different jurisdictions have been collated and compared (World Economic Forum 2013), and in 2016, the E15 Initiative, a collaboration of the World Economic Forum and International Centre for Trade and Sustainable Development (ICTSD), called for reform of the ASCM to better address energy subsidies (ICSTD and World Economic Forum 2016; Horlick and Clarke 2016). The E15 Initiative has recommended as one of its policy options that members 'mandate full disclosure of fossil fuel subsidies under WTO rules, affirm that fossil fuel subsidies are actionable subsidies under those rules, and agree on the gradual phase-out and ultimate prohibition of such subsidies' (ICSTD and World Economic Forum, 2016, Policy Option 16).

Given the current geopolitical context, RTAs are the likely place to implement these policy options. For example, New Zealand reportedly attempted to incorporate a 'best endeavours' clause to phase out fossil fuel subsidies in the TPP, although this was ultimately unsuccessful (Munro 2016). The yet-to-be-ratified free trade agreement between the EU and Singapore restates and extends the category of prohibited subsidies from the ASCM but excludes subsidies to the coal industry (Article 12.7). More generally, it recognizes 'the need to ensure that, when developing public support systems for fossils fuels, proper account is taken of the need to reduce greenhouse gas emissions and to limit distortions of trade as much as possible' (Article 13.11). The current suite of RTA negotiations will be important in setting out disciplines on fossil fuel subsidies, which may then be taken up in a multilateral setting at a later date. As has occurred in the fisheries context, such efforts will 
require leadership of RTA members, a core group of subsidizing members within the WTO or in other forums such as G20, and an outreach to other international regimes.

\section{Fragmentation and interaction}

The final part of this article considers the issues of fragmentation and regime interaction that attend reform efforts for fisheries subsidies and fossil fuel subsidies. This is assisted by drawing on the notion of 'regimes', the definition of which can be hybridized as 'sets of norms, decision-making procedures and organisations coalescing around functional issue-areas and dominated by particular modes of behaviour, assumptions and biases' (Young 2012, 11; see also Krasner 1983; FischerLescano and Teubner 2004). The analysis below incorporates the insight that institutions are themselves highly influential in managing regime interplay (Gehring and Oberthür 2011).

\subsection{Negotiations and inter-regime learning}

An important issue in the fisheries subsidies context has been the question of how a trade regime dominated by particular assumptions, behaviour and biases can understand the ecological and ecosystem aspects of fisheries. In previous work I have demonstrated that the WTO negotiations have not simply relied on states to convey the necessary information and learning via trade delegates (notwithstanding the important grouping of the 'Friends of Fish'). Although policy coordination within states was a necessary part of inter-regime learning (especially as between trade, environment and fisheries ministries), it was not sufficient, and the negotiations also 
had to rely on international organizations such as the FAO and the United Nations Environment Programme (UNEP) and non-state actors such as the World Wide Fund for Nature (WWF) and the ICTSD (Young 2009). One of the implications of that analysis was to draw attention to the deliberative and scrutinizing role of those nonstate actors.

In fossil fuel subsidy reform, this orientation towards a deliberative (rather than representative) model will be equally necessary. Clearly, states will play a major role: indeed, the Friends of Fish was hailed as a useful precedent for energy subsidies (Bigdeli 2008), and the Friends of Fossil Fuel Subsidy Reform grouping has been influential in setting objectives. Yet, as Rive (2016) has shown, the objectives of the Friends of Fossil Fuel Subsidy Reform may be geared more towards the interests of fossil-fuel producing states, and it would be remiss not to include other perspectives and interests when 'educating' the trade regime. International organizations such as the International Energy Agency, the Organisation for Economic Co-operation and Development, and the Secretariat of the United Nations Framework Convention on Climate Change will play a role, but so too will non-state actors such as the ICTSD, the World Economic Forum, and the Global Subsidies Initiative. With an energy regime complex that is even more diffuse than fisheries, the politics of data gathering, information sharing, and the production of knowledge will be even sharper. Legal rules providing for participation, transparency and observership in negotiations, as developed in the fisheries subsidies context (Young 2009), will be important.

A related point is that the fisheries subsidies issue has benefited from a relatively accessible discussion during the Doha Round (with negotiating proposals made public on the WTO website) as compared to the more secretive negotiations of the TPP, which were highly criticized for a lack of openness and which were accessed 
instead from unauthorized publications of draft texts by Wikileaks. If the fossil fuel subsidies issue bypasses the multilateral setting and is negotiated within closed regional trade agreements instead, inter-regime learning and deliberation may be compromised.

\subsection{Inter-regime links in the proposed rules}

Studies on regime interaction also emphasize the ongoing mutual dependency of regimes in the implementation of rules. For example, the Chair's text for fisheries subsidies at the WTO utilized existing fisheries norms and institutions in classifying prohibited fisheries subsidies (Young 2009). It included a prohibition on 'subsidies the benefits of which are conferred on any vessel engaged in illegal, unreported or unregulated fishing', citing directly to the FAO's international plan of action (WTO 2007, Article I.1(h), footnote 81). Similar wording has been advanced by the negotiating proposals of 2015 and 2016 and, as cited above, by the signed text of the TPP.

The TPP signed text referenced the FAO IUU standard in its acknowledgement of the need for individual and collective action to address the problems of overfishing (Article 20.16.2), but it went further than this in directly invoking fisheries management standards in its prohibitions. It prohibited subsidies that were provided to any fishing vessel that had been listed by a regional fisheries management organization (RFMO) or arrangement for IUU fishing, or subsidies that were used for fishing for overfished stocks, as determined by concepts of maximum sustainable yield or by standards of RFMOs or domestic jurisdictions (Article 20.16.5(a) and (b)). These provisions are a direct example of the trade regime 
allowing another regime to decide upon an element on which its rules depend. Moreover, TPP parties were to endeavour not to undermine catch or trade documentation schemes operated by RFMOs, intergovernmental organizations (such as the FAO) or other arrangements where those TPP parties were not members of those organizations or arrangements (Article 20.16.14). As such, even if a TPP party had failed to agree to one of the relevant fisheries management regimes (through ratification and membership), it effectively waived the pacta tertiis principle for these circumstances. The result is that the TPP would have strengthened fisheries management regimes, whether or not all TPP parties had signed up to those regimes.

While this result would have been a positive one for fisheries management and sustainability, it also gives rise to questions of sovereignty and consent. For positivist international lawyers, interacting legal regimes can threaten to impose norms to which states have not directly consented (Young 2015). For example, if a dispute were to arise over whether a state had violated the prohibitions on certain subsidies alleged to contribute to overfishing, the respondent state might dispute an RFMO's determination about the status of a fish stock, especially if it was not a member of the relevant RFMO. An admittedly more unlikely scenario would have a WTO member disputing a FAO classification of IUU fishing because it is not a member of the FAO (relevant, for example, for entities such as Hong Kong and Chinese Taipei who are members of the WTO as customs territories rather than states, and who are not eligible for FAO membership). The issue may be more theoretical than practical, especially in the TPP context in which the relatively small number of 12 ratifying states made it more likely that there would be overlapping membership with multilateral regimes such as the FAO fisheries management regimes. However, arguments about the need for uniform membership between regimes have been made 
with some success by respondent states in WTO disputes (Young 2007), and it is important to be aware of them in both the fisheries and fossil fuel subsidy reform scenarios.

The answer to the challenge to sovereignty is to pose a more nuanced model of authority that allows trade and fisheries management regimes (or trade and energy regimes) to rely upon one another's norms and benchmarks even absent uniform state membership. This hinges on a notion that 'authority and contestability go hand in hand' (Young 2009; see also Scott 2004), which has developed in other areas of WTO law (such as the standards organizations that are referenced in the WTO Agreement on Technical Barriers to Trade) as well as European Union law. A similar idea has emerged in studies of informal international law-making, where a 'thick stakeholder consensus' can provide better legitimacy than sovereign consent (Pauwelyn et al. 2014). The idea here is that international courts can recognize the legal influence of informal norms if they meet requirements of procedural integrity by considering (i) the credibility of the norm-creating body; (ii) the transparency, openness and integrity of the norm's elaboration; and (iii) the substantive quality and acceptance of the norm (Pauwelyn et al. 2014).

Although there is not the space to develop this further in the current article, the identification of issues relating to the inter-regime links in the proposed disciplines on fisheries subsidies alerts us to broader and more structural questions about international law making and enforcement. In essence, WTO members should feel comfortable including in their agreements references to decisions or concepts from other regimes if those regimes are open, transparent, and contestable, and thus supported by a thick stakeholder consensus. These issues were apparently addressed by TPP parties in the crafting of the fisheries subsidies rules, with referenced 
instruments such as the FAO plan on IUU fishing developed in a transparent, inclusive, and publicly accessible way.

How will this develop in the fossil fuel subsidy context? Transparency has been a major theme of reform efforts (Bigdeli 2008), and the TPP fisheries provisions requiring parties to provide information about their fisheries subsidies expressly included fuel subsidies (Article 20.16.11). More generally, the Friends of Fossil Fuel Subsidy Reform have called for: 'Communication and transparency about the merits of subsidy policies and reform timetables, including through engagement with the general public and civil society stakeholders to ensure a smooth, inclusive, bottom-up approach to reform' (FFFSR 2015).

In regional trade agreements, too, there is increasing awareness of the need for enhanced systems for transparency in subsidies. The EU-Korea Free Trade Agreement, for example, requires each party to report annually to the other party on the 'total amount, type and the sectorial distribution of subsidies which are specific and may affect international trade' (Article 11.12.1). In addition, either party may request further information on any subsidy scheme or individual subsidies of the other party. While this does not identify particular subsidies such as fisheries subsidies or fossil fuel subsidies, it does address the need for greater transparency around subsidies as part of the reform process. ${ }^{8}$

The TPP raised expectations about some form of inter-regime links in proposed rules relating to fossil fuel subsidy reform due to a leaked draft of the environment chapter. Proposed article SS.15(6)) linked reform to the Parties' APEC commitments (TPP 2014):

\footnotetext{
${ }^{8}$ Article 11.11 of the EU-Korea FTA also deems additional categories of state assistance to be 'specific' for the purposes of Article 2 ASCM (prohibited subsidies), including subsidies to insolvent or ailing businesses. However, it expressly excludes subsidies to the coal industry.
} 
The Parties recognize their respective commitments in APEC to rationalize and phase out over the medium term inefficient fossil fuel subsidies that encourage wasteful consumption, while recognizing the importance of providing those in need with essential energy services. Accordingly, the Parties agree to undertake, as appropriate, cooperative and capacity building activities designed to facilitate effective implementation of these commitments, including in applying the APEC Voluntary Reporting Mechanism.

This provision was subsequently abandoned in favour of a weaker Article 20.15, which was entitled 'Transition to a Low Emissions and Resilient Economy' in the signed text and provided:

1. The Parties acknowledge that transition to a low emissions economy requires collective action.

2. The Parties recognise that each Party's actions to transition to a low emissions economy should reflect domestic circumstances and capabilities and, consistent with Article 20.12 (Cooperative Frameworks), Parties shall cooperate to address matters of joint or common interest. Areas of cooperation may include, but are not limited to: energy efficiency; development of costeffective, low-emissions technologies and alternative, clean and renewable energy sources; sustainable transport and sustainable urban infrastructure development; addressing deforestation and forest degradation; emissions monitoring; market and non-market mechanisms; low-emissions, resilient 
development and sharing of information and experiences in addressing this issue. Further, the Parties shall, as appropriate, engage in cooperative and capacity-building activities related to transitioning to a low emissions economy.

At the very least, the TPP parties showed that they were aware that climate change mitigation was being negotiated along specific pathways, but they were unwilling to link their commitments to those efforts. In comparison with the fisheries context, they were rather less bold in matters of regime interaction.

Questions surrounding legitimacy in regime interaction may direct attention to the more laggardly efforts at reform in the fossil fuel context as compared to the marine context. Theoretical questions surrounding 'authority and contestability' and 'thick stakeholder consensus' lead to a consideration of the stakeholders (including non-state actors as well as states) in regime interaction, and a review of their ability, and credibility, when participating in the elaboration of norms. This is especially needed when inter-regime links do not eventuate—such as the failed attempt to have fossil fuel subsidies addressed in the Paris Agreement or the TPP. The energy regime_ - or 'regime complex' (Van de Graaf 2013)_may be even more complicated than fisheries management regimes in this regard. Providing more scrutiny of stakeholders within the energy regime complex-who from many accounts are already adept at corporate lobbying on a scale that may even exceed the concentrated corporate interests in fisheries management-will be an important part of the assessment of legitimacy in the interaction between the trade, energy and climate regimes. For example, what types of biases exist in the energy regime if the state is still expected to support, through tax-payers' money, the exploration of carbon 
reserves when that same state, via the climate regime, has pledged to reduce greenhouse gas emissions? Is there a thick stakeholder consensus surrounding relevant rules and practices? If fossil fuel subsidy reform efforts within the trade regime are deaf to the need to reform fossil fuel production subsidies, it could be that important voices from the climate regime are not being heard.

For an international community committed to energy transitions, the early efforts at fisheries subsidies reform are instructive. The main lessons identified in this section relate to the interaction needed between the trade regime and other regimes. First, it is essential that learning about fossil fuel subsidies and energy policy depends on existing state practice and the expertise and understandings from a range of organizations. This include outreach and collaboration between a range of actors including: secretariats of intergovernmental organizations involved in (at least) climate, energy and trade; trade delegates (informed by the other domestic portfolios within their countries); non-governmental organizations; and epistemic networks of scientists and other experts. Over time, the awareness of overfishing and IUU fishing garnered from outside the trade regime has influenced the shape of the proposed trade disciplines in meaningful ways. Similar learning needs to occur from the energy regime and, perhaps more importantly, the climate regime, with its assessments of carbon budgets and the need to limit fossil fuel production. Second, the implementation of fossil fuel subsidy rules will require ongoing interaction between regimes, and this can be included directly in the text of the reforms. For example, fossil fuel subsidy reform in domestic jurisdictions could be tied to that country's nationally determined contributions under the Paris Agreement (see van Asselt and Kulovesi, this issue), or a scientific notion of a carbon budget. Negotiators should not expect to have uniform state membership between regimes in these new rules, but can 
find support in making reference to decisions or concepts from other regimes if those regimes are open, transparent and contestable, and are accompanied by a thick stakeholder consensus. This may well direct attention to the need to address development issues in the fossil fuel subsidy reform context, which will likely draw on concepts of common but differentiated responsibilities from the climate regime. Third, an ongoing awareness of the voices that are prioritized or excluded from different regimes - and a way to assess and act on regime bias through procedural mechanisms - will be important in shaping the substance of the new rules, especially as those rules may well conflict with the special interests in fossil fuel production that have been resistant to international oversight thus far.

\section{Conclusion}

Fossil fuel subsidy reform can learn much from current and ongoing attempts to clarify and improve disciplines on fisheries subsides. This article has set out parallels in problem definition, which demonstrates that any question about state support of a sensitive and significant sector must be attendant to social, political and cultural factors. There is no natural and uncontested nature of a 'good' or 'bad' fisheries or fossil fuel subsidy, but there is mounting scientific evidence of the ecological effects of certain economic practices and the concepts of 'carbon budgets' and 'overfished stocks' provide some clarity in attempts at classification. This clarity will progress to agreed standards which, in the fisheries context, have centred on prohibitions for subsidies that support fishing efforts for already overfished stocks and IUU fishing. These standards were entrenched in a signed international agreement between major subsidizing states in the Trans-Pacific Partnership, and although they are unlikely to 
enter into force due to US policy decisions in other areas, they continue to animate reform proposals, including at the WTO.

This article has shown that the question of forum is central to the issues of subsidy reform: it is likely that the WTO, or trade delegates negotiating regional trade agreements, are the bodies that will assume governance. If so, the question of interaction between the trade regimes and other relevant regimes-including fisheries management, energy investment and climate change mitigation-must be posed. For fisheries subsidies reform, the current emphasis on regional or plurilateral efforts rests on a sustained earlier multilateral attempt at reform during the Doha Round, which involved trade delegates, a number of other intergovernmental organizations, including the FAO and UNEP, and a range of non-governmental organizations such as WWF and the ICTSD. This outreach and emphasis on open deliberation was crucial, especially in pre-empting concerns that the WTO was acting outside its competence or expertise. The TPP, a more secretive affair, apparently benefited from these efforts in arriving at concrete disciplines that demonstrated knowledge about, and reliance on, fisheries management regimes.

Interaction between the trade regime and other regimes will continue in the implementation of any disciplines on subsidies that depend on established concepts and standards. For example, the TPP text included subsidy prohibitions that rested directly on decisions within fisheries management regimes such as IUU vessel lists and RFMO rulings. The confidence that TPP parties exhibited in relying on non-trade regimes (of which they may not have themselves been members) came from something other than direct state consent and sovereignty. Instead, I argue that models that link authority and contestability, and ensure a 'thick stakeholder consensus' in the underlying rules, provide legitimacy for states. This will be relevant to the reform of 
fossil fuel subsidies, where the focus will be on achieving openness, transparency, and contestability in the energy regime, including in the face of concentrated corporate interests that sit alongside other proponents of energy security as stakeholders. One should expect that if there is an appropriate inclusion of voices from the climate regime, the substance of the proposed reform of energy subsidies will incorporate standards and benchmarks relating to the obligations to keep carbon reserves unexplored and unexploited. Moreover, issues of development priorities and special and differential treatment, which have been central to fisheries subsidies reform, are likely to rely on the climate regime's concept of common but differentiated responsibilities and respective capabilities. Reform to fossil fuel and fisheries subsidies requires an attentiveness to a similar set of issues in order to develop effective, just and legitimate rules.

\section{Acknowledgements}

With thanks to participants at the workshop for the Research Network on Fragmentation and Complexity in Global Governance (REFRACT) sponsored by the Research Foundations-Flanders at the Vrije Universiteit Brussel on 26 June 2015 and especially to the workshop organizers Thijs Van de Graaf and Harro van Asselt. Thanks also to Elizabeth Sheargold for research assistance and Ben Czapnik and the two anonymous reviewers for helpful comments.

\section{References}

Bast, E., Doukas, A., Pickard, S., van der Burg, L., \& Whitley, S. (2015). Empty promises: G20 subsidies to oil, gas, and coal production. Washington, DC and London: Oil Change International and Overseas Development Institute. 
Bigdeli, S. Z. (2008). Will the "friends of climate" emerge in the WTO? The prospects of applying the "fisheries subsidies" model to energy subsidies. Carbon \& Climate Law Review, 2(1), 78-88.

Coady, D., Parry, I., Sears, L., \& Shang, B. (2015). How large are global energy subsidies. Washington, DC: IMF.

Fischer-Lescano, A., \& Teubner, G. (2004). Regime collisions: The vain search for legal unity in the fragmentation of global law. Michigan Journal of International Law, 25(4), 999-1046.

FAO. (2016). The state of world fisheries and aquaculture: Contributing to food security and nutrition for all. Rome: FAO.

FAO. (1993). Agreement to promote compliance with international conservation and management Measures by fishing vessels on the high seas. http://www.fao.org/docrep/meeting/003/x3130m/X3130E00.HTM.

FAO. (1995). Code of conduct for responsible fisheries. Rome: FAO.

FAO. (1999a). International Plan of Action (IPOA) for the management of fishing capacity. Rome: FAO.

FAO. (1999b) International Plan of Action (IPOA) to eliminate illegal, unregulated and unreported fishing. Rome: FAO.

FFFSR. (2015). Fossil-fuel subsidy reform communiqué. http://fffsr.org/communique/.

Gehring, T., \& Oberthür, S. (2011). Institutional interaction: Ten years of scholarly development. In S. Oberthür, \& O. S. Stokke (Eds.), Managing institutional complexity: Regime interplay and global environmental change (pp. 25-58). Cambridge, MA: MIT Press. 
Horlick, G. (2002). Problems with the compliance structure of the WTO dispute resolution process. In D. L. M. Kennedy, \& J. D. Southwick (Eds.), The political economy of international trade law: Essays in honour of Robert E. Hudec (pp. 636-645). Cambridge: Cambridge University Press.

Horlick, G., \& Clarke, P. A. (2016). Rethinking subsidy disciplines for the future. E15 Task Force on Rethinking International Disciplines - Policy Options Paper. E15Initiative. Geneva: ICTSD and World Economic Forum.

ICTSD and World Economic Forum. (2016). Strengthening the global trade and investment system for the $21^{\text {st }}$ century: E15 full thematic policy options. Geneva: ICTSD and World Economic Forum.

IEA. (2016). World energy outlook 2016. Paris: IEA.

IPCC. (2013). Summary for Policymakers. In T. F. Stocker, D. Qin, G.-K. Plattner, M. Tignor, S. K. Allen, J. Boschung, A. Nauels, Y. Xia, V. Bex, \& P. M. Midgley (Eds.), Climate change 2013: The physical science basis. Contribution of Working Group I to the Fifth Assessment Report of the Intergovernmental Panel on Climate Change (pp. 1-27). Cambridge: Cambridge University Press.

Krasner, S. (1983). Structural causes and regime consequences: Regimes as intervening variables. In S. Krasner (Ed.), International Regimes (pp. 1-21). Ithaca, NY: Cornell University Press.

Lang, K., Wooders, P., \& Kulovesi, K. (2010). Increasing the momentum of fossilfuel subsidy reform: A roadmap for international cooperation. Geneva: International Institute for Sustainable Development.

Markell, D. (2004) The North American Commission for Environmental Cooperation after ten years: Lessons about institutional structure and public participation in 
governance. Loyola of Los Angeles International \& Comparative Law Review, 26(3), 341-357.

Martini, R. (2012). Fuel tax concessions in the fisheries sector. Paris: OECD.

Munro, J. (2016). Climate change in the TPP and the TTIP. In P. Delimatsis (Ed.), Research handbook on climate change and trade law (pp. 394-414). Cheltenham: Edward Elgar.

Orford, A. (2015). Food security, free trade, and the battle for the state. Journal of International Law and International Relations, 11(2), 1-67.

Pauwelyn, J., Wessel, R., \& Wouters, J. (2014). When structures become shackles: Stagnation and dynamics in international lawmaking. European Journal of International Law, 25(3), 733-763.

Porter, G. (2004). Analysing the resource impacts of fisheries subsidies: A matrix approach. Geneva: United Nations Environment Programme.

Pramoda, G., Nakamurab, K., Pitchera, T. J., \& Delagran, L. (2014). Estimates of illegal and unreported fish in seafood imports to the USA. Marine Policy, 48, $102-113$.

Rive, V. (2016). Fossil fuel subsidy reform: A New Zealand perspective on the international law framework. New Zealand Universities Law Review, 27(1), 73101.

Scott, J. (2004). International trade and environmental governance: Relating rules (and standards) in the EU and the WTO. European Journal of International Law, 15(2), 307-354.

Scott, J. (2015). The geographical scope of the EU's climate responsibilities. Cambridge Yearbook of European Legal Studies, 17, 1-29. 
Sumaila, U. R., Lam, V., Le Manach, F., Swartz, W., \& Pauly, D. (2013). Global fisheries

subsidies.

http://www.europarl.europa.eu/RegData/etudes/note/join/2013/513978/IPOLPECH NT(2013)513978 EN.pdf.

Sumaila, U. R., Lam, V., Le Manach, F., Swartz, W., \& Pauly, D. (2016) Global fisheries subsidies: An updated estimate. Marine Policy, 69, 189-193.

Sumaila, U. R., Khan, A. S., Dyck, A. J., Watson, R. A., Munro, G. R., Tyedmers, P. H., \& Pauly, D. (2010). A bottom-up re-estimation of global fisheries subsidies. Journal of Bioeconomics, 12(3), 201-225.

Tipping, A. (2016). Building on progress in fisheries subsidies disciplines. Marine Policy, 69, 202-208.

TPP. (2014). Secret TPP treaty: Environment chapter for all 12 nations. https://wikileaks.org/tpp-enviro/.

Trebilcock, M. (2015). A sceptical reaction to both diagnosis and prescription. Journal of International Law and International Relations, 11(2), 142-146.

Trebilcock, M., \& Pue, K. (2015). The puzzle of agricultural exceptionalism in international trade policy. Journal of International Economic Law, 18(2), 233260.

UN. (2002). Plan of Implementation of the World Summit on Sustainable Development. A/CONF.199/20, 4 September 2002.

UN. (2015). Transforming our world: the 2030 Agenda for Sustainable Development. A/RES/70/1, 25 September 2015.

UNCTAD, FAO and UNEP. (2016). Regulating Fisheries Subsidies must be an Integral Part of the Implementation of the 2030 Sustainable Development 
Agenda, Joint Statement, Fourteenth session of the United Nations Conference on Trade and Development, 17-20 July 2016.

Van de Graaf, T. (2013) The politics and institutions of global energy governance. Palgrave Macmillan

Von Moltke, A. (Ed.) (2011). Fisheries subsidies, sustainable development and the WTO. London: Earthscan.

Whitley, S. and van der Burg, L. (2015). Fossil fuel subsidy reform: from rhetoric to reality. Washington, DC: New Climate Economy.

Wilson, R. W., Millero, F. J., Taylro, J. R., Walsh, P. J., Christensen, V., Jennings, S., \& Grosell, M. (2009). Contribution of fish to the marine inorganic carbon cycle. Science, 323(5912), 359-362.

Witbooi, E. (2008). The infusion of sustainability into bilateral fisheries agreements with developing countries: The European Union example. Marine Policy, 32, $669-679$.

World Bank. (2016). The sunken billions revisited: Progress and challenges in global marine fisheries. Overview. Washington, DC: World Bank.

World Economic Forum. (2013). Lessons drawn from reforms of energy subsidies. http://www3.weforum.org/docs/GAC13/WEF GAC13 LessonsReformsEnergy Subsidies Report.pdf.

WTO. (1998). United States-Import Prohibitions on Certain Shrimp and Shrimp Products, Report of the Appellate Body, WT/DS58/AB/R (12 October 1998).

WTO. (2001). WTO Ministerial Declaration adopted on 14 November 2001,WTO Doc. WT/MIN(01)/DEC/1.

WTO. (2005). WTO Ministerial Declaration adopted on 18 December 2005, WT/MIN(05)/DEC. 
WTO. (2006a). Negotiating Group on Rules. Expanding the Prohibited Red Light Subsidy Category - Paper from the United States, TN/RL/GEN/94 (16 January 2006).

WTO. (2006b). Negotiating Group on Rules - Subsidies - Submission of the European Communities, TN/RL/GEN/135 (24 April 2006).

WTO. (2007). Draft Consolidated Chair's text of the AD and SCM Agreements, TN/RL/W/213 (30 November 2007), Annex VIII to the SCM Agreement (8793).

WTO. (2008). Negotiating Group on Rules, Working Document from the Chairman, TN/RL/W/232 (28 May 2008), Annex C - Fisheries Subsidies.

WTO. (2011). Negotiating Group on Rules. Communication from the Chairman, TN/RL/W/254, (21 April 2011).

WTO. (2012). United States-Measures Affecting Trade in Large Civil Aircraft. Reports of the Appellate Body, WT/353/AB/R (12 March 2012).

WTO. (2013a). Canada-Certain Measures Affecting the Renewable Energy Generation Sector-Canada-Measures Relating to the Feed-in Tariff Program. Reports of the Appellate Body, WT/DS412/AB/R, WT/DS426/AB/R (6 May 2013).

WTO. (2013b). Ministerial statement on behalf of Argentina, Australia, Chile, Columbia, Costa Rica, Ecuador, Iceland, New Zealand, Norway, Pakistan, Peru, Philippines, United States, WT/MIN(13)/49 (18 December 2013).

WTO. (2015a). Negotiating Group on Rules. Communication from Argentina, Iceland, New Zealand, Norway, Peru, and Uruguay, WTO Doc TN/RL/W/258 (19 June 2015). 
WTO. (2015b). Negotiating Group on Rules. ACP Proposal, TN/RL/W/267 (13 November 2015).

WTO. (2015). WTO Ministerial Declaration, adopted at Nairobi on 19 December 2015, WT/MIN(15)DEC.

WTO. (2016a). Joint Statement regarding Fisheries Subsidies' by Argentina, Australia, Canada, Chile, Colombia, New Zealand, Norway, Papua New Guinea, Peru, Singapore, Switzerland, Uruguay, and the United States (14 September 2016).

WTO. (2016b). Negotiating Group on Rules: Advancing Toward a Multilateral Outcome on Fisheries Subsidies in the WTO (European Union), TN/R/GEN/161 (20 October 2016).

WTO. (2016c). Negotiating Group on Rules: Principles and Elements for Concluding Negotiations on Fisheries Subsidies Rules in the WTO (Submission by Rwanda on behalf of the ACP Group), TN/RL/GEN/182 (16 November 2016).

WTO. (2016d). Negotiating Group on Rules: WTO Fisheries Subsidies - A Framework to Guide the Multilateral Negotiations to Eliminate Harmful Fisheries Subsidies (Argentina, Colombia, Costa Rica, Panama, Peru and Uruguay), TN/RL/GEN/183 (29 November 2016).

Young, M. A. (2007). The WTO's use of relevant rules of international law: an analysis of the Biotech case. International and Comparative Law Quarterly 56(4), 907-929.

Young, M. A. (2009). Fragmentation or interaction: The WTO, fisheries subsidies, and international law. World Trade Review, 8(4), 477-515. 
Young, M. A. (2012). Introduction: The productive friction between regimes. In M. A. Young (Ed.), Regime interaction in international law: Facing fragmentation (pp. 1-19). Cambridge: Cambridge University Press.

Young, M. A. (2015). Fragmentation, regime interaction and sovereignty. In C. Chinkin, \& F. Baetens (Eds), Sovereignty, statehood and state responsibility (pp. 71-89). Cambridge: Cambridge University Press.

Young, M. A. (2016). International trade law compatibility of market-related measures to combat illegal, unreported and unregulated (IUU) fishing. Marine Policy, 69, 209-219. 


\section{University Library}

\section{- M M N E R VA A gateway to Melbourne's research publications}

Minerva Access is the Institutional Repository of The University of Melbourne

Author/s:

Young, MA

Title:

Energy transitions and trade law: lessons from the reform of fisheries subsidies

Date:

2017-06-01

Citation:

Young, M. A. (2017). Energy transitions and trade law: lessons from the reform of fisheries subsidies. INTERNATIONAL ENVIRONMENTAL AGREEMENTS-POLITICS LAW AND ECONOMICS, 17 (3), pp.371-390. https://doi.org/10.1007/s10784-017-9360-2.

Persistent Link:

http://hdl.handle.net/11343/283092 